\title{
Mapping Isolated Places in School in Concurrence with Bullying Possibility Elements
}

\author{
Azna Abdul Wahab¹, Siti Rasidah Md Sakip² \\ 1 Universiti Teknologi MARA, Shah Alam 40450, Selangor, Malaysia \\ 2 Department of Landscape Architecture, Faculty of Architecture, Planning \& Surveying, \\ Universiti Teknologi MARA Perak Branch, Seri Iskandar Campus 32610, Perak, Malaysia \\ 2 Green Safe Cities Research Group, Universiti Teknologi MARA, Shah Alam Campus 40450, Selangor, Malaysia \\ azna.abdulwahab@yahoo.com, sitir704@perak.uitm.edu.my \\ Tel :(+60) 1116446048
}

\begin{abstract}
This study aims to indicate isolated places in school in concurrence with bullying specific environments and elements. Observation student's density was conducted in the school and analysed using the Geographic Information System (GIS). A thorough observation conducted at the isolated areas using CPTED element checklist. The results of the study reveal that the CPTED element which triggers the isolated places mostly cause by maintenance condition on window and wall. Rather than that, shrubs and decorative sculpture could block the sight in isolated areas. These results may help the school's authorities to optimise existing features to decrease the possibility of bullying.
\end{abstract}

Keywords: CPTED; physical environment, bullying

eISSN: 2398-4287 @ 2019. The Authors. Published for AMER ABRA cE-Bs by e-International Publishing House, Ltd., UK. This is an open access article under the CC BYNC-ND license (http://creativecommons.org/licenses/by-nc-nd/4.0). Peer-review under responsibility of AMER (Association of Malaysian Environment-Behaviour Researchers), ABRA (Association of Behavioural Researchers on Asians) and cE-Bs (Centre for Environment-Behaviour Studies), Faculty of Architecture, Planning \& Surveying, Universiti Teknologi MARA, Malaysia.

DOI: https://doi.org/10.21834/e-bpj.v4i12.1913

\subsection{Introduction}

Bullying is a growing social problem affecting millions of students globally. For the last thirty years, bullying amongst students has been acknowledged as a severe problem in schools worldwide (Roland \& Galloway, 2002). Previous longitudinal studies conducted have discovered a consistent and robust connection between bullying during adolescence and criminal behaviour later during adulthood (Renda, Vassallo, \& Edwards, 2011; Sourander et al., 2011). The problem of bullying amongst students is, unfortunately, a global issue, occurring not only in Malaysia but also around the world. According to Poyner (1983), human movement and behaviour is critically shaped and influenced by the design and layout of one's physical environment. Architectural design and layout of buildings and street networks can significantly affect and modify how individuals intermingle, utilise and move about in their environment (Reynald, 2014). Some of the previous researchers believed that there is a connection between a crime committed and an individual's physical environment (Liebermann \& Kruger, 2004). The opportunities that exist in a particular environment could contribute to and encourage a criminal in his or her decision to attack a targeted victim (Liebermann \& Kruger, 2004). The environmental element is a crucial component in the criminal's decision-making process on whether or not to commit a crime. (Loukaitou-Sideris \& Eck, 2007).

Most research studies have found that it is common for bullying to occur in playgrounds, bathrooms and hallways of schools, with the actual physical location varying from school to school. However, these surveys fail to take into account the unique physical, structural configuration of each school. Hence, the results cannot pinpoint specific locations where bullying acts are likely to occur within the structural and social environment of a school. The studies do, however, include the indoor and outdoor school areas, as well as the

eISSN: 2398-4287 @ 2019. The Authors. Published for AMER ABRA cE-Bs by e-International Publishing House, Ltd., UK. This is an open access article under the CC BYNC-ND license (http://creativecommons.org/licenses/by-nc-nd/4.0). Peer-review under responsibility of AMER (Association of Malaysian Environment-Behaviour Researchers), ABRA (Association of Behavioural Researchers on Asians) and cE-Bs (Centre for Environment-Behaviour Studies), Faculty of Architecture, Planning \& Surveying, Universiti Teknologi MARA, Malaysia. DOI: https://doi.org/10.21834/e-bpj.v4i12.1913 
areas behind schools. Hence, using GIS as a tool of analysis, this paper will evaluate the likelihood of acts of bullying occurring in different locations at schools. It also evaluates how the physical environment contributes to such actions taking place.

\subsection{Purpose of the study}

The purpose of this study was to examine the characteristic of isolated areas in school in concurrence with bullying possibility elements. From the investigation, is expected to propose the features of the safe bully environment in school.

\subsection{The objective of the study}

In line with the purpose, the objectivity of the research was to examine the presence of isolated area in school and to determine the physical environment features using Crime Prevention through Environmental Design (CPTED) elements.

\subsection{Literature Review}

Bullying was negative actions inflicted upon a person who struggles to defend himself/herself which consistently reoccurs over some time (Wan Ismail et al., 2010). Physical bullying, verbal bullying and social bullying were the common forms of bullying behaviour. Verbal bullying that can be done quietly and covertly was the reason where the children can avoid detection and punishment was the most widely performed type of bullying (Mohamad Salleh \& Zainal, 2014; Rigby, 2008).

\subsection{Environmental design and bullying behaviour}

The essence of environmental design is the interaction amongst the various factors such as physical, social, environmental, individual and community factors (Sakip, Johari, \& Salleh, 2012). The architectural design and structural layout of buildings and street networks significantly shape the decision-making process of individuals in relations of how they interact, utilise and move about in their environment (Reynald, 2014). Crime is believed to be linked to one's physical environment (Liebermann \& Kruger, 2004). It proposed that opportunities existing in one's environment can propel a criminal to bully a targeted victim (Liebermann \& Kruger, 2004). The environmental element is one of the factors deliberated upon by criminals before deciding whether or not to commit a crime (LoukaitouSideris \& Eck, 2007). The physical school structure and layout may also play a crucial role in providing bullies with the opportunity to commit acts of bullying (Atlas \& Pepler, 1998). Craig et al. (2000), in his study, reported that there is a higher probability of victimisation occurring in unstructured environments.

\subsection{School environment and bullying}

The physical environment thought to be one of the determining factors impelling crime and instilling fear of crime in society (Sakip et al., 2012). Areas which are isolated, or which are not visible due to being barricaded by landscaping or structural layouts, are assumed to amplify the risk of an attack and increase levels of fear (Lorenc et al., 2013). Areas that lack of excellent visibility or show signs of neglect commonly elevate an individual's level of fear associated with the physical environment (Lee \& Ha, 2015; Lorenc et al., 2013). Filth, rot, graffiti, trash, signs of disrepair, and dilapidation of buildings generally viewed as contributing towards instilling fear in an individual (Lorenc et al., 2013; Wilcox, Augustine, \& Clayton, 2006). Although most of the outdoor space in front of the elementary schools enjoy excellent visibility, generally, the areas behind the schools do not (Lee \& Ha, 2015).

There is evidence about the relationship between physical disorder (e.g., broken windows and poor building condition) and bullying behaviour in some studies (Durán-Narucki, 2008; Grana et al., 2010; Kumar, O' Malley, \& Johnston, 2008; Waller, 2013; Wilcox et al., 2006). Lack of monitoring has made these out of the way locations prime spots for vandalism and graffiti and contributing to the feeling of being unsafe.

\subsection{Geographic Information Systems (GIS)}

The development and use of Graphic Information Systems (GIS) as a method of crime analysis is a relatively new analytical method. It is where geographical maps present an integral part of the crime analysis. A review on several previous studies on crime mapping confirmed that GIS enables fast and efficient. The analytic methods used, supported decision making about the problem of crime in the studied environment. Robert (2016) had concluded that GIS created maps could be useful visuals when searching for crime and demographic patterns.

The GIS allows researchers to analyse the landscapes of a social environment to understand best how physical locations contribute to or affect the outcomes (Elwood 2002; Fyfe et al. 2009). Migliaccio, Raskauskas, and Schmidtlein (2017) had to use spatial analysis GIS in mapping the bullying hotspots in school block in California school. Thus, in this paper, the researcher would like to use GIS as a method that indicated isolated places in the school. To support the result, the researcher would want to check the environmental features in the isolated area using Crime Prevention through Environmental Design (CPTED) score checklist.

\subsection{Methodology}




\subsection{Study area}

The study area was at School A in Selangor, Malaysia. In 2017, Selangor had recorded the highest number of hotspot school as much as 76 schools, followed by Johor (63), Negeri Sembilan (40), Pahang (37) and Pulau Pinang (37) (Mohd, 2018). The selected school was one of the 402 listed schools as hotspots school for discipline problem by the Ministry of Education.

\subsection{Data collection method}

In this study, the measurement to identify bullying behaviour (physical bullying, verbal bullying and social bullying) is measured using the questionnaire. School layout was used in the observation to observed student density at a specific location. The number of students determines by the student density of certain areas in the school found present at that location within a particular time. Each student present in an area marked as one dot in the school layout. This study uses GIS software to identify areas where acts of bullying are likely to occur. To reassess the extent to which CPTED conditions are present in an isolated area in school, a constructed checklist on CPTED elements of territoriality, surveillance, and maintenance was used.

\subsection{Data analysis method}

SPSS analysis was used to analyse the nature of bullying behaviour in school. To examine the presence of isolated area in school; the variable will be measured based on student density at a specific area within the recess time. The observation used a copy of the school layout to indicate student density. The inspection only conducted during school recess time as the student actively engages with other students. The density of a specific area in the school represents the number of students at a particular place. One dot in the school layout represents one student. Then, the school layout was transferred into GIS software to analyse. An isolated area represents the colour of the green space.

\subsection{Findings}

\subsection{Nature of Bullying in School}

A total of 96 students who randomly chosen had answered the questionnaire on bullying incident that occurs in their school and the location of bullying. Table 4.4 shows the percentage of the student being bullied in school. The results indicated that 66 per cent of the students in the school had been bullied for the past 12 months. One per cent of the students in the school had been bullied at least once a week. Meanwhile, 14 per cent of the students had been bullied two to three times in a month followed with 51 per cent of students had been bullied less than once a month.

\begin{tabular}{|c|c|c|c|c|c|c|}
\hline \multirow[b]{2}{*}{ School } & \multicolumn{5}{|c|}{ The Percentage of Frequency Student Being Bullied (\%) } & \multirow[b]{2}{*}{ Tota } \\
\hline & $\begin{array}{c}\text { Almost Always } \\
\text { (2-3 times a week) }\end{array}$ & $\begin{array}{c}\text { Often } \\
\text { (Once a week) }\end{array}$ & $\begin{array}{c}\text { Sometimes } \\
\text { (2-3 times in a month) }\end{array}$ & $\begin{array}{c}\text { Seldom } \\
\text { (Less than once a } \\
\text { month) }\end{array}$ & $\begin{array}{c}\text { Almost Never } \\
\text { (Never) }\end{array}$ & \\
\hline School A & 0 & 1 & 14 & 51 & 34 & 100 \\
\hline Total Bullying & \multicolumn{4}{|c|}{66} & 34 & 100 \\
\hline
\end{tabular}

The most common type of bullying that occur in School A was verbal bullying (55\%). Social bullying was the second-highest for School $A(52 \%)$ followed by physical bullying (42\%). Two per cent of the student reported physically and verbally bullied at least once a week.

Table 2. The percentage of frequency student being bullied based on the type of bullying

\begin{tabular}{|c|c|c|c|c|c|c|c|c|c|c|c|c|c|c|c|}
\hline \multirow[b]{2}{*}{$\begin{array}{l}\text { Type of Bullying } \\
\text { The Percentage of } \\
\text { Frequency Student } \\
\text { Being Bullied in } \\
\text { School (\%) }\end{array}$} & \multicolumn{5}{|c|}{ Physical Bullying } & \multicolumn{5}{|c|}{ Verbal Bullying } & \multicolumn{5}{|c|}{ Social Bullying } \\
\hline & 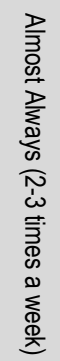 & 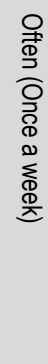 & 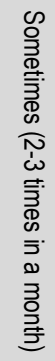 & 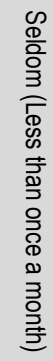 & 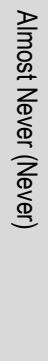 & 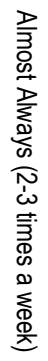 & 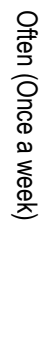 & 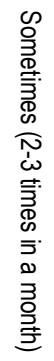 & 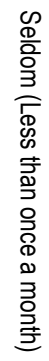 & 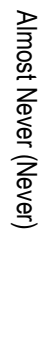 & 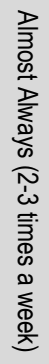 & 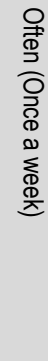 & 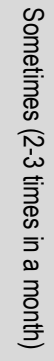 & 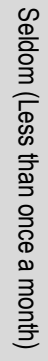 & 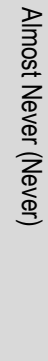 \\
\hline School A & 0 & 2 & 5 & 34 & 58 & 0 & 2 & 21 & 32 & 45 & 0 & 0 & 18 & 34 & 48 \\
\hline Total & \multicolumn{4}{|c|}{42} & 58 & \multicolumn{4}{|c|}{55} & 45 & \multicolumn{4}{|c|}{52} & 48 \\
\hline
\end{tabular}

The result of this study supports the previous finding that indicated verbal bullying was the most widely performed type of bullying among the students. It can be done quietly and covertly where the student can avoid detection and punishment compare with physical bullying. 


\subsection{Isolated Area}

The variable to examine the presence of isolated area in school will be measured based on student density at a specific area within the recess time.

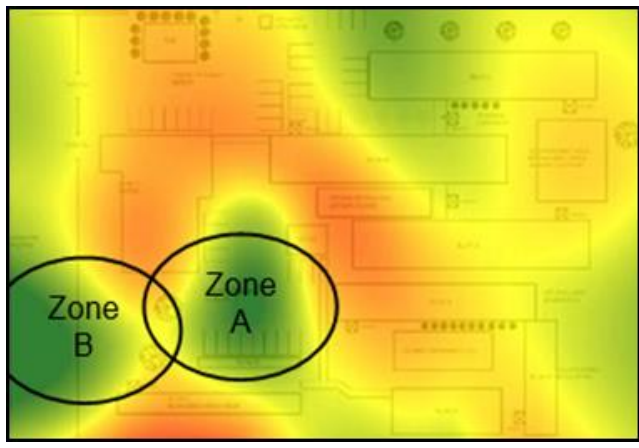

(a)

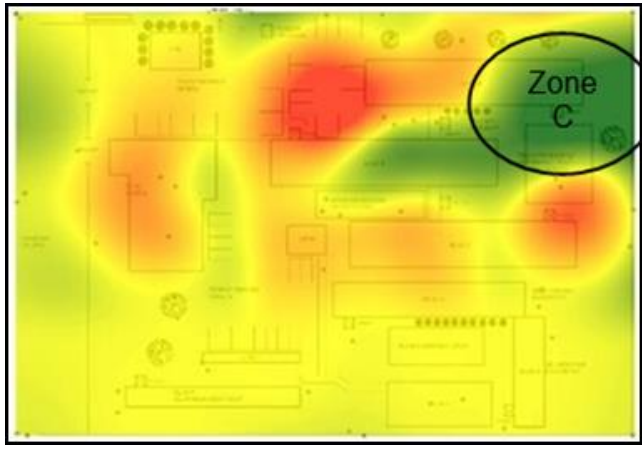

(b)

Fig. 1 (a) Isolated school area for Zone A and Zone B; (b) Isolated school area for Zone C

Figure 1 above showed three isolated Zone areas that had the probability of being bullying area in School A. Resulting from the GIS analysis; the three isolated Zone marked as Zone A, Zone B and Zone C.

\subsubsection{Isolated Area at Zone A}

The car park area was identified as an isolated area at Zone A. The area surrounded by the school building, which had the highest visibility for surveillance. There are not many places of concealment at the centre of the car park, other than behind vehicles (when it is full).
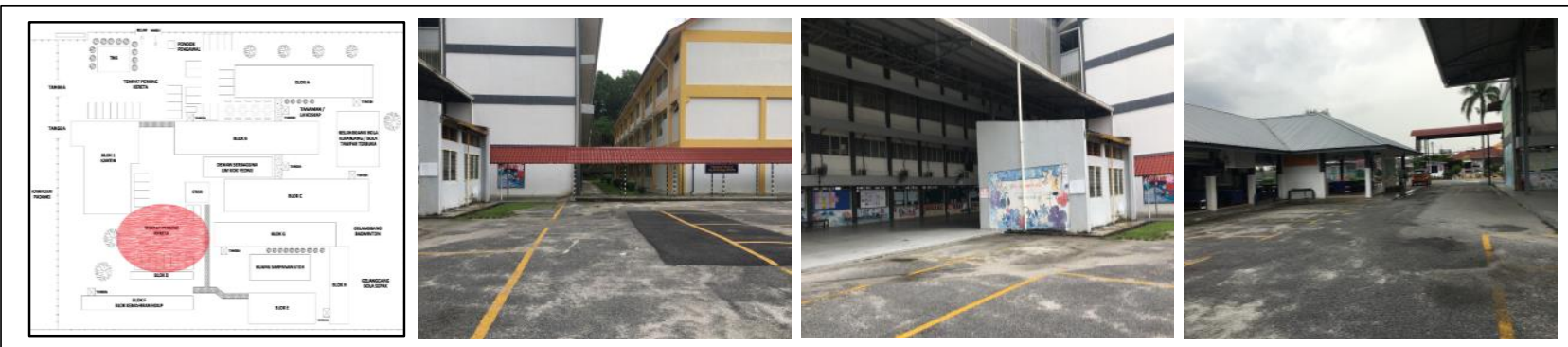

Fig. 2 The school environment area at Zone A

\subsubsection{Isolated Area at Zone B}
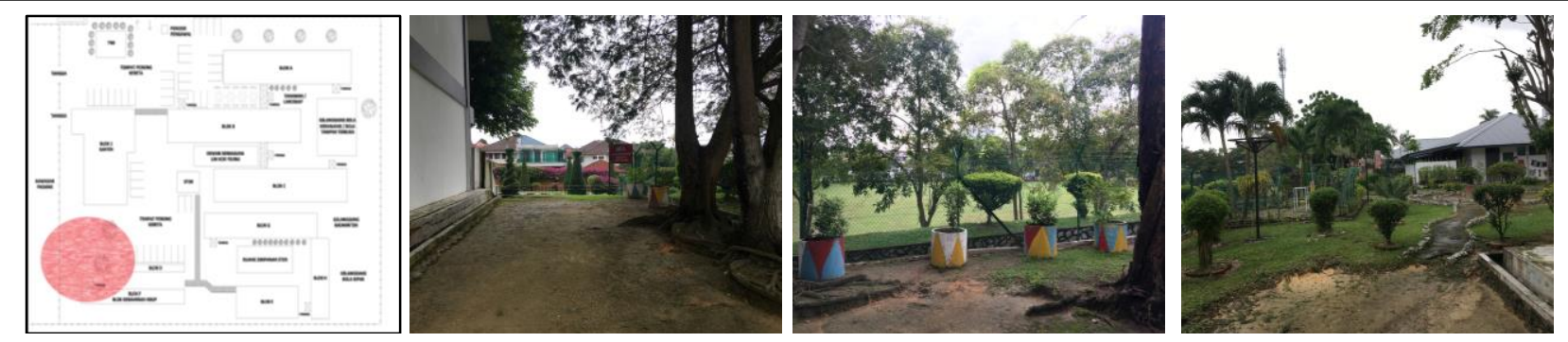

Fig 3 The school environment area at Zone B

Zone B was behind the school building and beside the school field. Sometimes some students hang out at the area when the recess time. The landscaped of the area was grow with tall trees and bushes. Near the area was the school garden which landscape with 
trees and sculpture. The visibility of the area from other buildings was low due to the distance of the area was more than 50 meters from other buildings.

\subsubsection{Isolated Area at Zone C}

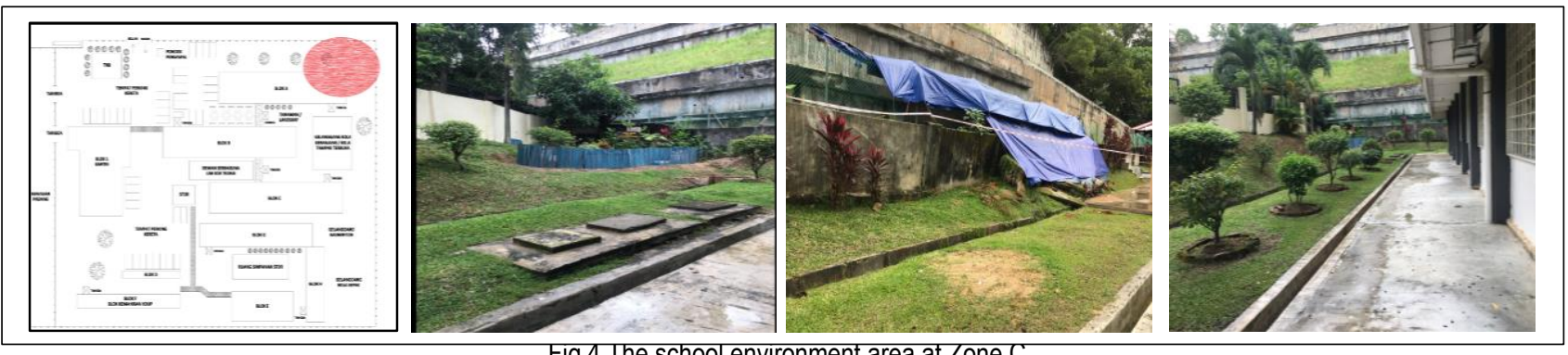

Fig 4 The school environment area at Lone C

Zone $\mathrm{C}$ was behind the school building. The landscape was a little hilly at the area, which makes the visibility of the area low. There was also a scene of landslide occurrence in the area which can endanger students. A safety tape was used in the landslide area to be noted by the student that the area was not allowed to be the approach. The landslide was cover with plastic to prevent it from getting worse when it rains.

\subsection{Physical Environment Features}

Table 3 below showed the detail on physical environment features in school. The observation of three CPTED element at the isolated Zone includes territoriality element, surveillance element and maintenance element.

Table 3. The physical environment features based on CPTED elements

\begin{tabular}{|c|c|c|c|c|}
\hline \multirow[t]{2}{*}{ CPTED } & \multirow[t]{2}{*}{ Items } & \multicolumn{3}{|c|}{ Number of Items } \\
\hline & & Zone A & Zone B & Zone $\mathrm{C}$ \\
\hline \multirow[t]{3}{*}{ Territoriality } & Signage + & - & 1 & 2 \\
\hline & Ownership + & 2 & 2 & 10 \\
\hline & Total & 2 & 3 & 12 \\
\hline \multirow[t]{7}{*}{ Surveillance } & Windows that enable the visibility of the area + & 12 & - & - \\
\hline & Windows design that had barriers covering more than $10 \%$ of visibility- & - & - & - \\
\hline & The direction of sight/vision that allows the area to be seen + & 4 & 1 & 2 \\
\hline & Decorative sculpture that had height over 0.9 meters - & - & - & 2 \\
\hline & Shrubs that had height over 0.9 meter - & - & 6 & - \\
\hline & Trees that had height over 2.0 meter - & 1 & 8 & 4 \\
\hline & Total & 17 & 15 & 8 \\
\hline \multirow[t]{6}{*}{ Maintenance } & Graffiti in the area - & - & 1 & - \\
\hline & Dry leaves and litter - & - & - & - \\
\hline & Broken window - & - & 2 & - \\
\hline & Bad condition of wall (ex; peeling of paint) - & - & - & 1 \\
\hline & Broken door - & - & 1 & - \\
\hline & Total & 0 & 4 & 1 \\
\hline
\end{tabular}

Territoriality element, which consists of signage and ownership elements, were observed. A total of two ownership elements found in Zone A. In Zone B, a total of three territoriality elements were observed, which were a sign and two elements of ownership. A high number of territoriality elements found in Zone C (12 elements). Two signs and ten ownership elements were observed in the area.

There were some elements also were observed under surveillance elements. A total of 17 elements found in Zone A. There was a total of 12 windows that enable the visibility of Zone A. The direction of sight that allows the area to be seen also satisfying with four directions of view. There was a tree that had a height over 2.0 meter that blocking the visibility of the area. Meanwhile, a total of 15 elements were observed in Zone B. The area had a poor direction of sight that allowed to be seen. Several shrubs and trees were also blocking the visibility of the area. In Zone $\mathrm{C}$, a total of eight surveillance elements were observed in the area. The area can be seen from two directions of the sight. The presence of decorative sculpture and trees also blocking the visibility of the area to be seen.

There were no graffiti, dry leaves, litters, broken windows and door in Zone A. However, graffiti, broken windows and door were observed in Zone B. A lousy condition of peeling paint was seen in Zone C.

\subsection{Discussion}

\subsection{Nature of Bullying in School}

This descriptive analysis study examined the nature of bullying in secondary school. The result of this study support previous finding that indicated verbal bullying was the most widely performed type of bullying among the students (Akpunne, Lanre-Babalola, \& S. Alo, 2019; Klomek, Sourander, \& Gould, 2010; Mary Ann Solar Armas, Hugo F. Gutiérrez-Crespo, \& Raúl Alberto Ruiz Arias, 2019; Mohamad 
Salleh \& Zainal, 2014). Verbal bullies use words to hurt or humiliate another person. Verbal bullying includes name-calling, insulting, making racist comments and constant teasing. This type of bullying is the easiest to inflict on other children. It is quick and to the point.

\subsection{Physical Environment Features in Isolated Area}

Based on the analysis of the isolated area, there are three characteristics of the isolated area in school. The first characteristic was an unfunctional and unconducive area. The second characteristic was low visibility, and the third characteristic was a sign of neglect at a specific area.

A functional conducive landscaped is directly or indirectly assists in providing space for leisure and interacting with landscape components (Ali, Rostam, \& Awang, 2015). The occurrence of the landslide in Zone C gives a lousy environment to look in the area. The environment could decrease the sense of ownership in the area. Based on Table 3, the territoriality element was the highest in Zone $\mathrm{C}$ in school. The area showed the best sense of territoriality. The landslide that occurs all of sudden must be managed quickly and adequately for student safety. By eliminating any unassigned spaces are one of territoriality component. The authorities also must ensure all the areas have a clearly defined and designated purpose. Routinely cared-for and monitored is also a component of territoriality (Cozen, Saville, \& Hillier, 2005). Schools that include permanent student artwork in the interior spaces of school buildings also will foster student ownership (Killeen, Evans, \& Danko, 2003). The application of colours and usage materials also may influence students behaviour (Shamsuddin, Bahauddin, \& Aziz, 2012) as the student enjoy being at the bench as they provide not just seating areas but also plants and water elements.

Visibility is an essential factor that affects the fear of crime in environments and one of the isolated area characteristics in school. Although most exterior spaces of elementary schools are high-visibility areas, the hottest spots were behind the areas of the buildings, which were low invisibility (Lee \& Ha, 2015). The statement supported by the result of isolated places in Zone B and Zone C which were behind the building and hilly landscape. A place which is not visible because of isolated which are obstructed by landscaping and building design can increase the risk of attack and hence fear (Lorenc et al., 2013). Nonetheless, hard landscape such as decorative sculpture and soft landscape such as trees and bushes should be maintained and appropriately placed as it can block the visibility in a specific area.

Several factors in the physical environment are perceived to impact on fear of crime, including visibility and signs of neglected (Lee \& Ha, 2015; Lorenc et al., 2013) was the characteristics of an isolated area in school. Dirt, decay, graffiti, litter and other sign of neglect of the environment are drivers of fear (Lorenc et al., 2013; Wilcox et al., 2006). The condition of maintenance at Zone B may have neglected by the school's authorities. The location of the area that is behind the building is the reason it may often overlook.

\subsection{Conclusion and Recommendation}

Three types of bullying often occur in school, which are physical bullying, verbal bullying and social bullying. Between the three types of bullying, verbal bullying was the most prevalence occur in school compared to physical bullying and social bullying.

The school authorities must be noted the characteristics of the isolated area and eliminate it through manipulation of the design, layout and physical features. Apart from that, the probability of bullying occur is presumed to be related to the physical environment can be added as it plays a significant aspect in the developing behaviours. The element such as water sculpture, bench, notice board, and garden furniture play an essential role in creating a sense of ownership in the student. The level of specific components of landscapes at the school in the region is significant can develop a sense of ownership by setting up gazebo, pergola, bench, garden tables, signboards and flower pots. More green area and seating area is better for a school environment. The visibility of certain places also must be noted more as it plays a crucial element in negative behaviour. Foliage (mainly tall thin trees) and overgrown bushes must be adequately maintained. The neglected sign of specific areas such as dirt, decay, and litter must be eliminated and appropriately managed. Thus, there is an association between various aspects of the physical environment around the schools and bullying among students. By manipulation of the design and layout, physical features can influence the chances of a crime to occur by affecting violent behaviour. Environmental design theories are emphasising on the physical environment as a tool to control and block any of opportunities to offend. Students have a fundamental right to learn in a safe, supportive environment and treated with respect.

A school's physical environment may help create a safe environment. The physical environment of a student's surroundings plays an essential role in providing them with a sense of comfort and safety. Thus, in the analysis of physical environments, it can be concluded that there are three characteristics of an isolated area in school which specific physical environments could be of negative influence if they are not well-maintained. Better layout and design of school block buildings would help towards improving the level of surveillance over students.

\section{Limitation of the Study}

The study only focuses on one secondary school which had indicated to has a discipline problem by the Ministry of Education. There are limitations on the school design in obtaining a comprehensive picture of factors associated with bullying victimisation due to the different design and arrangement of school. 


\section{Acknowledgements}

In realising this study, the researchers would like to thank the Royal Malaysian Police (PDRM), Ministry of Higher Education by the Malaysian Government in supporting this research by the Fundamental Research Grant Scheme (FRGS) of (FRGS/1/2015/SSI11/UITM/02/12).

\section{References}

Akpunne, B. C., Lanre-Babalola, F., \& S. Alo, F. (2019). Classroom Size as a Predictor of Bullying Behaviour among Secondary School Adolescents in Nigeria. Asian Journal of Education and Social Studies.

Ali, S. M., Rostam, K., \& Awang, A. H. (2015). School Landscape Environments in Assisting the Learning Process and in Appreciating the Natural Environment. Procedia - Social and Behavioral Sciences, 202(December 2014), 189-198.

Andershed, H., Kerr, M., \& Stattin, H. (2001). Bullying in School and Violence on the Streets: Are the Same People Involved? Journal of Scandinavian Studies in Criminology and Crime Prevention, 2(1), 31-49.

Atlas, R. S., \& Pepler, D. J. (1998). Observations of Bullying in the Classroom. Journal of Educational Research, 92(2), 86-99.

Boulton, M. J., Trueman, M., \& Flemington, I. (2002). Associations between Secondary School Pupils' Definitions of Bullying, Attitudes towards Bullying, and Tendencies to Engage in Bullying: Age and sex differences. Educational Studies, 28(January 2015), 353-370.

Cozen, P. M., Saville, G., \& Hillier, D. (2005). Crime Prevention Through Environmental Design ( CPTED ): A Review And Modern Bibliography. Property Management, 23(5), 328-356.

Craig, W. M., Pepler, D. J., \& Atlas, R. (2000). Observation of Bullying in the Playground and in the Classroom. School Psychology International, 21(1), 22-36.

Durán-Narucki, V. (2008). School building condition, school attendance, and academic achievement in New York City public schools: A mediation model. Journal of Environmental Psychology, 28(3), 278-286.

Grana, R. A., Black, D., Sun, P., Rohrbach, L. A., Gunning, M., \& Sussman, S. (2010). School Disrepair and Substance Use Among Regular and Alternative High School Students. Journal of School Health, 80(8), 387-393.

Killeen, J. P., Evans, G. W., \& Danko, S. (2003). The Role Of Permanent Student Artwork In Students' Sense Of Ownership In An Elementary School. Environment and Behavior, 35(2), 250-263

Kim, M. J., Catalano, R. F., Haggerty, K. P., \& Abbott, R. D. (2011). Bullying at elementary school and problem behaviour in young adulthood: A study of bullying, violence and substance use from age 11 to age 21. Criminal Behaviour and Mental Health, 21, 136-144.

Klomek, A. B., Sourander, A., \& Gould, M. (2010). The Association of Suicide and Bullying in Childhood Longitudinal Research Findings. Canadian Journal of Psychiatry, $55(5), 282-288$

Kumar, R., O' Malley, P. M., \& Johnston, L. D. (2008). Association Between Physical Environment of Secondary Schools and Student Problem Behavior. Environment and $B, 40(4), 455-486$.

Lee, S., \& Ha, M. (2015). The Duality of Visibility : Does Visibility Increase or Decrease the Fear of Crime in Schools' Exterior Environments ? Journal of Asian Architecture and Building Engineering, 14(1), 145-152.

Liebermann, S., \& Kruger, T. (2004). Crime Prevention Through Environmental Design (CPTED). 9th International Conference on Crime Prevention Environmental Design.

Lorenc, T., Petticrew, M., Whitehead, M., Neary, D., Clayton, S., Wright, K., ... Renton, A. (2013). Fear of crime and the environment : systematic review of UK qualitative evidence.

Loukaitou-Sideris, A., \& Eck, J. E. (2007). Crime prevention and active living. American Journal of Health Promotion, 21, 380-389.

Mary Ann Solar Armas, Hugo F. Gutiérrez-Crespo, \& Raúl Alberto Ruiz Arias. (2019). Factors Associated With The Presence Of Bullying In Secondary School Students Of A State School In The District Of El Porvenir, Peru. Revista Internacional de Salud Materno Fetal.

Migliaccio, T., Raskauskas, J., \& Schmidtlein, M. (2017). Mapping the landscapes of bullying. Learning Environments Research, 20(3), 365-382.

Mohamad Salleh, N., \& Zainal, K. (2014). Bullying Among Secondary School Students in Malaysia: A Case Study. International Education Studies, 7(13), $184-191$.

Mohd, H. (2018). Revealed: Full list of 402 Malaysian schools with disciplinary, drug issues. New Straits Times.

Olweus, D. (1993). Victimization by peers: Antecedents and long-term outcomes. In Social withdrawal, inhibition, and shyness in childhood.

Olweus, Dan. (2011). Bullying at school and later criminality: Findings from three Swedish community samples of males. Criminal Behavior and Mental Health, 21, 151156.

Poyner, B. (1983). Design against crime: Beyond defensible space.

Renda, J., Vassallo, S., \& Edwards, B. (2011). Bullying in early adolescence and its association with anti-social behaviour, criminality and violence 6 and 10 years later. Criminal Behaviour and Mental Health, 21, 117-127. 
Reynald, D. M. (2014). Environmental Design and Crime Events. Journal of Contemporary Criminal Justice, 31(1), 71-89.

Rigby, K. (2008). Children and bullying: How parents and educators can reduce bullying at school.

Robert, R. A. (2016). Exploring Residential Crime Prediction with GIS - Demographic Profiles vs Top Offender Location: A Rochester, Minnesota USA Case Study. Papers in Resource Analysis, 19, 14 pp.

Roland, E., \& Galloway, D. (2002). Classroom influences on bullying. Education Research, 44(3), 299-312.

Sakip, S. R. M., Johari, N., \& Salleh, M. N. M. (2012). The Relationship between Crime Prevention through Environmental Design and Fear of Crime. Procedia - Social and Behavioral Sciences, 68, 628-636.

Shamsuddin, S., Bahauddin, H., \& Aziz, N. A. (2012). Relationship between the Outdoor Physical Environment and Student's Social Behaviour in Urban Secondary School. Procedia - Social and Behavioral Sciences, 50(July), 148-160.

Sourander, A., Brunstein Klomek, A., Kumpulainen, K., Puustjarvi, A., Elonheimo, H., Ristkari, T., ... Ronning, J. A. (2011). Bullying at age eight and criminality in adulthood: Findings from the Finnish nationwide 1981 Birth cohort study. Social Psychiatry and Psychiatric Epidemiology, 46(12), 1211-1219.

Waller, K. J. (2013). A Correlational Study Of The Levels Of School Violence Aand The School's Physical Environment As Perceived By Teachers.

Wan Ismail, W. S., Tan, S. M. K., Nik Jaafar, N. R., Iryani, T., Syamsul, S., Aniza, A., \& Zasmani, S. (2010). School Bullying Among Standard Six Students Attending Primary National Schools In The Federal Territory Oo Kuala Lumpur: The Prevalence and Associated Socio-Demographic Factors. Malaysian Journal of Psychiatry, 18(1).

Wang, J., lannotti, R. J., \& Nansel, T. R. (2009). School Bullying Among Adolescents in the United States: Physical, Verbal, Relational, and Cyber. Journal of Adolescent Health, 45(4), 368-375. https://doi.org/10.1016/j.jadohealth.2009.03.021

Wilcox, P., Augustine, M. C., \& Clayton, R. R. (2006). Physical environment and crime and misconduct in Kentucky schools. The Journal of Primary Prevention, 27(3), 293-313. 